\title{
Brigands in Pointe Shoes and Selfless Spirits: Salvage and Salvation in Nineteenth-Century Ballets
}

IRIS JULIA BUEHRLE

\begin{abstract}
:
This paper deals with scenes of salvage and salvation in a number of nineteenthcentury ballets which were mostly inspired by works of literature, and their afterlives.

The term 'salvage' will be used in several metaphorical senses here. By tracing back 'salvage' to its wider etymological origins in the Latin word 'saluus', which refers to both physical and spiritual salvation, I will employ this term to describe the saving of the bodies and souls of ballet protagonists. I will argue that the evolution of ballet costumes and technique was linked to the appearance of a number of unconventional salvage scenes in which traditional gender roles were reversed and women saved men. Several examples will be used to demonstrate how ballet librettists changed the literary sources when they transposed them into libretti in order to add these scenes. The term 'salvage' can also refer to 'the saving and collection of waste material [... ] for recycling'. ${ }^{1}$ Now, in this sense ballet libretti 'recycled' literary source texts, and so enact salvage through adaptation. What is more, elements from previous libretti were recycled in nineteenth-century ballets, through the re-enactment of certain archetypal situations, including rescue scenes and acts of spiritual salvation.
\end{abstract}

Keywords: rescue, survival, salvation, recycling, translation, transformation, adaptation, ballet, literature 
The first half of the nineteenth century saw a spectacular rise in the importance of the ballerina. The predominance of the male dancer, which could be traced back to the sixteenthand seventeenth-century Italian and French court ballet, was overthrown. From the late 1820s onwards, ballet, like contemporary literature and opera, began to move away from mythological subjects and increasingly revolved around mystery, the gothic, the supernatural and the exotic. Instead of nymphs and goddesses, female dancers began to embody ethereal, weightless spirits. Literature, opera and ballet were closely linked in an age in which ballets were usually performed alongside or as parts of operas, and their libretti were frequently written by poets or opera librettists. Some ballets were based on works of literature, whose plots were often significantly modified in order to suit the requirements of the genre and balletic conventions of the time. The new subjects of ballets and the enhanced focus on female dancers led to an evolution of ballet costumes - which had traditionally been long, heavy and cumbersome for women - and technique. ${ }^{2}$ From the second decade of the nineteenth century onwards, some ballerinas managed, through considerable muscular effort, to lift themselves onto the very tips of their toes in soft shoes that were lightly padded at the front. The padding was gradually reinforced and the shoes became more solid, which eventually led to the development of the pointe shoe. If the pointe technique began as little more than a virtuosic achievement, ballerinas such as Marie Taglioni used it for a dramatic purpose: the lightness with which the female dancers appeared to hover above the ground on the tips of their toes perfectly expressed the evanescence of the sylphs and spirits they embodied. Female dancers began to wear light gauze skirts, which allowed them to move more freely, and the newly introduced gas lighting wrapped them in a mysterious halo. Consequently, the ballerina began to appear as an unattainable creature whose physical elevation (which was often aided by flying machines) and evanescence could either be threatening - they were weightless and graceful, but they also had dangerous seductive or 
destructive powers - or it could be a sign of their spiritual elevation and ideal purity. A similar development can be observed in contemporary works of literature which featured idealized or dangerously seductive and often demonic female figures. Poets such as Théophile Gautier, whose literary writings contain femmes fatales (for instance the female protagonists in Une nuit de Cléopâtre and La Morte Amoureuse) and idealized, unattainable women (for example Spirite in the eponymous novella) also wrote ballet libretti. Since the female dancers seemed to possess almost supernatural capacities, they were often the most powerful figures in nineteenth-century ballets which were frequently named after their heroines. As a result, male protagonists were sometimes rescued by female characters. The latter can be put into two categories; on the one hand, there are the virtuous angels who save men's lives or souls through the power of their love, and often die in the process - this type frequently appears in ballets with tragic endings. On the other hand, there are the determined women who take major risks to rescue their lovers usually from physical death. This type of heroine can mostly be found in ballets with happy endings.

In the first decades of the nineteenth century, many ballets were based on comic operas $^{3}$ or literary sources which already contained singing and dance, and were often well known to the audience. Ballet masters usually adapted the sources themselves, and they did not hesitate to change them in order to suit the requirements of their medium, the expectations of their audience, or their personal preferences. One example would be the ballet Danina oder Joko, der brasilianische Affe which the Italian ballet master Filippo Taglioni created at the court of Duke Karl Eugen of Württemberg in Stuttgart in $1826 .{ }^{4}$ It was based on Gabriel de Lurieu and Edmond Rochefort's play Jocko, ou le singe du Brésil, which was premiered in Paris in 1825 . The source contained songs and extensive danced parts which were choreographed by the ballet master Frédéric-Auguste Blache, and it acquired particular fame 
through the performance of the acclaimed comic dancer Charles Mazurier in the role of Jocko. 5

In the ballet which Taglioni conceived and choreographed, the shift of emphasis in the title from the monkey to the main female protagonist indicates a change of perspective, and in the ballet, the role of Danina (who is called Cora in the source) became much more important than in the play. This is partly due to the requirements of the ballet genre, in which female counterparts to the male protagonists are usually needed in order to create pas de deux (duos in ballet). Furthermore, the choreographer's daughter Marie was cast in the role of Danina, and the ballet was a vehicle to highlight her extraordinary skills. Taglioni did not hesitate to change the literary source accordingly: his Danina is a courageous and powerful slave who not only proves worthy of the love of a man of much higher social status, but she also saves a monkey by killing a snake with her bow and arrow - in the source, this heroic deed is attributed to a man. ${ }^{6}$ Following her success in Danina, Marie Taglioni was invited to present herself at the Paris Opera. The critic of Le Figaro wrote after Taglioni's first performance in Paris: 'Ses débuts feront époque. C'est le romantisme appliqué à la danse.' ('Her debut will make history. It is Romanticism applied to dance.' $)^{7}$ She subsequently became the first female superstar of ballet, and the subject of innumerable lithographs, paintings and statues. In early nineteenth-century France, ballets usually ended happily: Louis Henry’s Hamlet, which was performed at the Théâtre de la Porte Saint-Martin in Paris in 1816, for instance, concludes with the appearance of old Hamlet's ghost, who saves his son's life and hands the crown over to him. ${ }^{8}$ It therefore came as a surprise when in 1830 , the librettist Eugène Scribe chose to adapt Antoine-François Prévost's eighteenth-century novel Manon Lescaut and remained faithful to the tragic ending of the source. ${ }^{9}$ As in the novel, Manon and Des Grieux get lost in the swamp, but in the ballet, help arrives before Des Grieux notices that Manon is already dead. The combination of two shocks in close succession - in this case, the 
happy surprise that the couple will be saved, and the devastating revelation that she is already dead - was very popular in nineteenth-century opera and ballet. ${ }^{10}$ However, the librettist emphasizes that Manon's soul is saved since she embraces marriage and Christian values just before her death. The last dialogue between Manon and her lover Des Grieux sounds rather like an operatic duet (in the ballet, this dialogue would have been expressed through mime):

Pardonne-moi à mon heure dernière, pardonne-moi les tourmens que je t'ai causés: je n'ai jamais aimé que toi, je le jure. - Manon! Manon! je te crois. - Eh bien! nomme-moi ton épouse. - Oui, devant Dieu qui nous contemple, je te nomme ma femme, ma compagne; et si je te perds je ne te survivrai pas! Manon! toujours unis!

(Forgive me at my last breath, forgive me the torments I have caused you: I have never loved anyone else but you, I swear it. - Manon! Manon! I believe you. - Well then! call me your wife. - Yes, before God who looks down on us, I call you my wife, my companion; and if I lose you I will not survive you! Manon! forever united!) ${ }^{11}$

In contrast, twentieth-century choreographers often omitted all references to religion and spiritual salvation from their ballets. In a 1974 adaptation of Manon Lescaut by the British choreographer Kenneth MacMillan, the heroine is physically and spiritually destroyed throughout the third act and seems like a broken puppet in the final scene, which ends with Des Grieux's lonely, piercing despair as he realizes that his lover is dead. ${ }^{12}$

The saving of characters from spiritual rather than physical damage became a defining characteristic of Romantic operas and ballets. A year after Manon Lescaut, the premier of Meyerbeer's opera Robert le Diable in 1831 started an aesthetic revolution at the Paris Opera. In act 3 of this work, Marie Taglioni appeared as the Abbess leading a group of dead nuns 
who had broken their vows. Their alluring dancing tempts the main character, Robert, into committing a sacrilegious deed, but he is eventually saved from signing a pact with the devil by the singing of monks, and by a woman who loves him. ${ }^{13}$

The 'Ballet of the Nuns' the first 'ballet blanc' (white ballet), became a model for many subsequent works, including the second act of the ballet La Sylphide, which was premiered at the Paris Opera in $1832 .{ }^{14}$ The libretto, which was written by the tenor Adolphe Nourrit who had sung the role of Robert in Robert le Diable, was based on the novella Trilby by Charles Nodier. The choreography was by Filippo Taglioni, who had also created the 'Ballet of the Nuns'. It united several characteristics that would become identified with the Romantic ballet: its 'exotic' setting in an imaginary Scotland peopled with witches and spirits; a relatively simple plot; character dances of the countryfolk and scenes set among graceful female supernatural creatures.

Instead of Charles Nodier's male spirit Trilby who falls in love with a mortal woman, the ballet revolves around a female sylph who seduces a young Scotsman. The sylph was danced by the choreographer's daughter, and it became her most emblematic role. Instead of showing off her virtuosity, Marie Taglioni used the relatively new pointe technique in order to express the supernatural lightness of the elusive sylph who dies as her lover tries to keep her earthbound by depriving her of her wings. According to Théophile Gautier, '[c]e ballet commença pour la chorégraphie une ère nouvelle, et ce fut par lui que le romantisme s'introduisit dans le domaine de Terpsichore' ('this ballet started a new era for choreography, and it introduced Romanticism into the domain of Terpsichore'). ${ }^{15}$ Ballet subsequently became an important part of the Romantic movement; the dance historian Parmenia Migel even claimed that the Romantic ballet 'was, no doubt, the supreme expression of the Romantic era'. ${ }^{16}$ 
A few years later, Gautier wrote the libretto of what was to become the most famous Romantic ballet, Giselle, in cooperation with the librettist Jules-Henri Vernoy de SaintGeorges. The ballet, which was premiered at the Paris Opera in 1841, was inspired by an episode in Heinrich Heine's Elementary Spirits. Heine briefly relates the legend of the Wilis, spirits of women who expired before their wedding and force every man whom they meet at night to dance until he drops dead from exhaustion. Typically for ballets of the period, the librettists used the literary source as a starting point to create a plot which suited the requirements of the genre. Like La Sylphide, Giselle contained a first act set in the human world and a second act set in a wood among supernatural beings. A Duke, Albert (nowadays usually called Albrecht), disguises himself as a peasant to court a village girl, Giselle. When she finds out that he is a nobleman and betrothed to another woman, she becomes mad, dies and turns into a Wili. In the second act, the repentant Albert visits Giselle's grave in the haunted wood, disregarding the danger to his life. Giselle forgives her lover and saves him from the evil spirits:

La reine et toutes les Wilis le poursuivent jusqu'au tombeau; mais Albert, toujours protégé par Giselle, arrive ainsi jusqu'à la croix, qu'il saisit; et au moment où Myrtha va le toucher de son sceptre, la branche enchantée se brise entre les mains de la reine, qui arrête, ainsi que toutes les Wilis, frappées de surprise et d'épouvante. ${ }^{17}$

(The queen and all the Wilis pursue him to the tomb; but Albert, still protected by Giselle, thus arrives at the cross, which he seizes; and as Myrtha is about to touch him with her sceptre, the enchanted branch breaks between the hands of the queen, who pauses, like all the other Wilis, struck with surprise and terror.) 
In most modern-day productions of Giselle which are based on the nineteenth-century version - for instance that by Patrice Bart and Eugène Polyakov for the Paris Opera Ballet, or that by Yvette Chauviré and Florence Clerc for La Scala Ballet - Albert and Giselle's arms are stretched out in this scene so that their bodies form a cross: she is an innocent victim of his deception, whereas he almost becomes a (guilty) victim of the revengeful women. Giselle interposes her body like a protective shield between her lover and the queen of the Wilis. Unlike Manon, however, Giselle might not manage to save her soul because her death could be considered - and has been depicted as such in various productions, such as Peter Wright's version for the Royal Ballet or Peter Schaufuss' production for the Deutsche Oper Berlin - as suicide, and she has to remain a Wili, a damned spirit killing men. ${ }^{18}$ Giselle is a prominent example of how a woman dies and risks damnation because of a man, and then selflessly forgives him and saves his life. In Robert le Diable and Giselle, the body and the soul of the endangered men are saved by a loving woman and their embracing of religion. Both are delivered by the ringing of church bells which indicate the end of the demonic spirits' power. These thematic parallels emphasize the strong links between ballet, opera and literature during the Romantic period.

Giselle was one of many examples of ballets about women who sacrificed themselves for their lovers. Considering the audience's taste for exotic settings during this period, the action was sometimes transposed into pagan contexts, but still kept its religious essence in many cases. One example is Joseph Mazilier's ballet Aelia et Mysis (Paris Opera, 1853), which was set in Rome under the Emperor Nero. ${ }^{19}$ Aelia saves her lover from the rage of the goddess Vesta by holding a pontifical branch over his head so that he can walk to freedom, after which she dies. Charles Nuitter and Arthur Saint-Léon's ballet La Source (Paris Opera, 1866), which is set in the Caucasus, revolves around a nymph who saves the life of a young 
man and eventually dies in order to make the cold-hearted woman he adores return his feelings - a supreme sacrifice, since she is herself in love with the young man. ${ }^{20}$

Some librettists introduced scenes of female sacrifice and salvation into their literary sources. Jules-Henri Vernoy de Saint-Georges' (libretto) and Joseph Mazilier's (choreography) ballet Le Diable amoureux (Paris Opera, 1840) was inspired by Jacques Cazotte's eponymous novel (1772), in which the main protagonist is seduced by the devil in the shape of a woman, but eventually escapes by hiding under his bed. Saint-Georges changed the plot and created a scene of double salvation in the end. In the ballet, the female demon Urielle tears up the pact which would have forced the man she loves to follow her, and dies. Urielle is saved from damnation by a rosary and a cross as an angel restores her to life and leads her to heaven. ${ }^{21}$ A 1989 ballet adaptation of the same novel by the French choreographer Roland Petit for the Marseille Ballet ends more grimly; it again illustrates the tendency of twentieth-century ballets to move away from spiritual salvation and focus more on male dancing. On a stage covered with smoke, the devil, who is danced by a man, passionately kisses the male hero, and both are swallowed up by the earth.

In his Faust, which he created in Milan in 1848, Jules Perrot deviated from the ending of his Goethean source in which Faust is absolved by angels. ${ }^{22}$ Perrot made Marguerite 'actively' save the title hero. After her execution, Marguerite's soul appears in the form of a flame as Mephistopheles tries to drag Faust to hell. The flame burns the infernal pact, and Faust is thus released from his bond. After a last desperate struggle over his soul, the infernal spirits are swallowed up by the earth. In 1948, a different version of the Faust legend by Werner Egk (music and libretto), Abraxas, was choreographed by Marcel Luipart at the Munich Opera, based on a ballet scenario by Heinrich Heine which was first published in 1851. ${ }^{23}$ Egk's ballet, which was banned after only five performances due to its indecency ${ }^{24}$ the authorities mainly objected to the eroticism of the Sabbath, which shows the union 
between Satan and his bride, the Archisposa - ended with Faust and a completely innocent Margarete being trampled to death by a furious mob. ${ }^{25}$ It is very likely that this bleak ending, in which neither of the protagonists is saved, alluded to Germany's recent past and the suffering during the war that had just ended.

Various echoes of Albert's betrayal and Giselle's death and forgiveness can be found in late nineteenth-century Russian ballet, which 'recycled' both the themes and certain structural elements of mid nineteenth-century ballets, such as the 'ballet blanc'. In Swan Lake, which was premiered in two versions in Moscow in 1877 and in Saint Petersburg in 1895 the Swan Lake ballets we see today are based on the second version -, the prince breaks his vow to the Swan Queen Odette, and both protagonists die. ${ }^{26}$ In La Bayadère (Saint Petersburg, 1877), the librettists Marius Petipa and Sergei Khudekov simplified the action of the source, Kalidasa's play Shakuntala, ${ }^{27}$ and brought it closer to that of Giselle. In La Bayadère, the warrior Solor swears to love the temple dancer Nikiya, but then consents to marry the daughter of the Rajah. Nikyia is killed by order of the Rajah's daughter, and the warrior subsequently begs her for forgiveness in the kingdom of the shades. As in Giselle and Swan Lake, the hero breaks a formal oath (visualized by the gesture of swearing), and like Albert in Giselle, he sets off to marry another woman after his lover's death. ${ }^{28}$ Unlike in Giselle, however, Solor eventually dies and is reunited with Nikiya in the afterlife. Both ballets contain a 'ballet blanc' in which the male protagonist meets a corps de ballet of supernatural female figures.

Many later ballets also contain plot elements taken from Giselle. In his 1999 Clavigo which he created at the Paris Opera, for instance Roland Petit took many liberties with his literary source, an eponymous play by Johann Wolfgang Goethe. The play revolves around a young man, Clavigo, who hesitates between his loyalty to a woman, Marie, and his ambition, a dilemma that eventually leads to the death of both Marie and Clavigo. Petit changed and 
simplified the action to resemble that of Giselle, for instance by showing how Clavigo seduces Marie and by introducing a madness scene and a scene involving Marie's spirit. As in Giselle, the first act of the ballet ends with the madness and death of Marie. During the second act, the dead Marie appears as a white-clad vision of purity to Clavigo, like the dead Giselle when Albert sees her spirit for the first time at the beginning of the second act. Clavigo, like Albert, repents, but he is not saved at the end of the ballet. In Petit's work, the focus shifts from the suffering of the female protagonist to the spiritual and physical plight of the male protagonist, who is at the centre of the ballet, as its title indicates. The ballet ends with a spectacular death solo for Clavigo. In one of the key images of the ballet, the wounded Clavigo covers his head with his shirt as if it were a shroud, thus resembling a martyr, but there is no hint that his soul is saved. ${ }^{29}$ Unlike Goethe, Petit does not allow his hero to be reconciled with his enemy and die at peace with the world, but his last solo is an anguished rebellion against death without any trace of acceptance of his fate or hope for deliverance. ${ }^{30}$ As in Le diable amoureux, Petit grants his hero no spiritual salvation, and he places particular emphasis on male dancing. He changes Goethe's play in order to bring the plot and characters closer to ballet stereotypes and make the action easier to express through dance.

There have also been some twentieth- and twenty-first-century reworkings of Giselle which bear the original title, such as Mats Ek's 1982 version for the Cullberg Ballet to Adolphe Adam's score and Akram Khan's 2016 version for the English National Ballet, with a new score by Vincenzo Lamagna. Ek eliminates the references to religion and the supernatural; his Giselle survives, but is locked up in a mental asylum. Akram Khan lets Giselle die under mysterious circumstances and reappear in the second act in a ghostly factory peopled by dead female workers. The Wilis brutally murder Hilarion, and when Albert appears, Myrtha, the queen of the Wilis, orders Giselle to kill her lover, but she disobeys. ${ }^{31}$ As in the 1841 version, Giselle saves Albert (here called Albrecht) from Myrtha, who tries to 
attack him with her staff, by shielding him with her body, but there is no cross. Instead of a spiritually reformed nobleman who returns to his former life and marries another woman, these versions eventually leave Albrecht crouching naked on the floor (Ek) or cast out from his own community (Khan). Thus, he shares the punishment that is only inflicted on Giselle in the nineteenth-century version. Both recent choreographies 'salvage' themes and structures of the original, but set their works in a completely new environment and omit the references to religion. Lamagna's composition 'recycles' elements from Adam's score.

Not all human heroines in nineteenth-century ballets died when they rescued their lovers. In comic ballets, which focus more on physical salvage than spiritual salvation, there is a significant number of women saving their companions from imminent physical danger, sometimes at the risk of their own lives. Several ballets feature young women who rescue men from brigands. They are often gipsies or bandits (or they believe or pretend that they are), which makes their transgressive behaviour seem more acceptable. In Paul Foucher's (libretto) and Joseph Mazilier's (choreography) ballet Paquita (Paris Opera, 1846), for instance, a gipsy - who is in fact the abducted daughter of a nobleman - takes considerable risks to save her beloved from a murder plot. ${ }^{32}$ Stella, the daughter of the chief of a band of smugglers in Arthur Saint-Léon's ballet Stella, ou les contrebandiers (Paris Opera, 1850), ${ }^{33}$ and the gipsy dancer Esmeralda in Perrot's ballet La Esmeralda (Her Majesty's Theatre, 1844) both save men from death at the last minute by declaring their willingness to marry them. Perrot's libretto for the latter ballet is based on Victor Hugo's novel Notre-Dame de Paris and on Hugo's own libretto for the opera La Esmeralda, but Perrot opted for a happy ending with several rescue scenes. ${ }^{34}$ In Jovita ou les boucaniers, the heroine disguises herself as a gipsy in order to save her lover from bandits. ${ }^{35}$ Saint-Georges' (libretto) and Mazilier's (choreography) ballet Le Corsaire (Paris Opera, 1856), which bears only the faintest resemblance to Lord Byron's eponymous poem, even includes a fight between the heroine 
and a pirate during which she strikes her opponent with a dagger in order to save her beloved. ${ }^{36}$

In Catarina, ou la fille du bandit (Her Majesty's Theatre, 1846), Perrot not only brought on stage a female bandit, but made her the leader of a gang of robbers: her father, who is mentioned in the title, is dead from the beginning of the ballet. Susan Au writes about the Romantic fashion to present female bandits in the theatre: 'The fascination with bandits and their lawless lives may have grown out of the Romantic restlessness and desire to escape from the conventions and restrictions of daily life. Women in particular were constrained by the implicit rules and regulations imposed upon respectable wives and mothers; thus, the image of a female bandit seemed doubly liberating. ${ }^{, 37}$ However, one could also argue that assertive female bandits were a fantasy designed to amuse and titillate the male spectators. Lynn Garafola's comment on cross-dressed female dancers (whose male costume showed off their figure) in nineteenth-century ballets could also be applied to some female bandits; she argues that 'In appearance, the feminine androgyne laid claim to another erotic nexus. Tall, imposing, and majestic, she added to the charm of wantonness the challenge of the amazon, that untamed Diana who so fascinated the nineteenth-century imagination. ${ }^{38}$ However, Catarina in the eponymous ballet reverts to the gendered stereotype of the sensitive and selfsacrificing woman: she falls in love with the painter Salvator Rosa and eventually gets stabbed as she throws herself between her lover and his jealous rival. ${ }^{39}$

Supernatural creatures sometimes rescue protagonists without any danger to themselves. This can again be women in love - as in Théophile Gautier's 1843 scenario for La Péri, in which a spirit saves her human lover and takes him to a Muslim paradise peopled with beautiful young women. ${ }^{40}$ In Filippo Taglioni's ballet La Révolte au sérail, which was originally called La Révolte des femmes (Paris Opera, 1833), the main couple is saved several times by a talisman given to the heroine by the Spirit of Womanhood. The Spirit eventually 
orders the tyrannical king who pursues the lovers to stop oppressing women. According to Ivor Guest, the critics did not allude to the unusual subject of women's liberation in their reviews and considered it as an innocuous, delightful divertissement. Thus, for instance, Jules Janin wrote about La Révolte au sérail: 'There are some who say that you need an idea to make a ballet. They are mistaken. To make a ballet you just need dancers - or rather danseuses, for we have ousted the male dancers. Therefore, the less invention you have, the better your chances of creating a charming ballet. ${ }^{41}$ The need to display the danseuses certainly accounted for the fashion of setting nineteenth-century ballets in harems, ${ }^{42}$ but Taglioni gave the subject an interesting twist by letting the enslaved women fight for their right to choose their own lovers. Joellen A. Meglin notes that the ballet was probably not a serious political statement for the emancipation of women, but 'the reason for introducing the woman question seems to have been to make the ballet topical, titillating, and good theater'. However, several terms of the libretto recalled Saint-Simonian feminist movements, and Meglin notes 'some intriguing similarities between this balletic fiction and the historical facts of women's liberation. ${ }^{43}$

La Révolte au sérail was one of a number of 'Romantic' ballets which featured an entire army of women warriors, as the female slaves take up weapons to gain their freedom. ${ }^{44}$ Two years later, Filippo Taglioni wrote the libretto for and choreographed another ballet on a similar subject, Brézilia, ou la tribu des femmes (Paris Opera, 1835), which included only one male role. The title heroine saves the life of her lover, who is threatened by the man-hating queen of her Amazonian tribe, by winning several contests of skill, agility, grace, and dancing. The ballet was another showpiece for Marie Taglioni, and Jules Janin decreed that it was 'a work devoid of any idea, a piece of nonsense offered so coolly and composed with such seriousness that no one but her father has ever paid a more complete tribute to the genius of Mlle Taglioni by making her bear the brunt of such a piece as this' ${ }^{45}$ 
In 1852, Jules Perrot's ballet The War of the Women, or the Amazons of the ninth century was premiered in Saint Petersburg. ${ }^{46}$ In this work, a crowd of female warriors rescues a young woman from the clutches of a villain who has usurped the dukedom of Bohemia. The young woman subsequently dresses up as a soldier to free the rightful duke, whom she loves, from prison. With the help of a statue that comes to life and a trap that suddenly engulfs the usurper, the army of women warriors defeats the illegitimate duke and restores the rightful heir to the throne. ${ }^{47}$ According to Ivor Guest, the original libretto, which was modified due to censorship, probably contained no intervention of supernatural powers in the end, which would have made the women's triumph even more resounding. ${ }^{48}$

Many nineteenth-century ballet heroes were saved by their faith, which was sometimes embodied by the Virgin Mary. Auguste Bournonville's ballet Napoli (Copenhagen, 1842), for instance, deals with the adventures of a particularly devout young couple: an amulet given to them by a monk which contains the image of the Madonna delivers Teresina from her existence as a naiad, and Gennaro is prevented from committing suicide - an act entailing both physical destruction and spiritual damnation - by a statue of the Virgin Mary. As the seasprite Golfo orders the naiads to capture Teresina and kill Gennaro, '[Teresina] raises the amulet aloft and bids the spirits of the sea submit to the supreme power of heaven.' The spirits obey and let the couple leave after bestowing rich gifts on them. ${ }^{49}$

Considering the predilection of Romantic choreographers for supernatural creatures, it is hardly surprising that The Tempest was their most popular Shakespearean source (whereas the absence of significant adaptations of A Midsummer Night's Dream before Petipa's 1876 Saint Petersburg version is unexpected). However, their adaptations often deviated markedly from the play they were based on. One example was Filippo Taglioni's Miranda (London, 1838), in which a young Spaniard is saved from evil spirits by the title heroine, who is the daughter of the Spirit of Good. ${ }^{50}$ It is noteworthy, though by no means unusual, that Taglioni 
got rid of Prospero, the central character in Shakespeare's play: older, philosophically minded men make rather inappropriate protagonists for a ballet. According to Hélène LaplaceClaverie, Prospero's character is impossible to transpose into ballet; she asks: 'Imagine-t-on le plus complexe des héros shakespeariens exprimant à l'aide de pirouettes et d'entrechats ses idées sur le pouvoir, la mort ou la création artistique?' ('Can we imagine Shakespeare's most complex protagonist expressing his thoughts on power, death and artistic creation through pirouettes and entrechats?'). ${ }^{51}$ Furthermore, the focus on Miranda once again gave Taglioni the opportunity to show off the skills of his star daughter.

La Tempête was the first Shakespeare-inspired ballet to be performed at the Paris Opera in 1834, in a version by Adolphe Nourrit (libretto) and Jean Coralli (choreography). Its libretto is rather loosely based on the play: in the ballet, the orphaned daughter of a Greek priest, Lea, is rescued from the Turks by two spirits, Oberon and Ariel. Years later, the spirits cause a shipwreck which washes ashore the young Spaniard Fernando. Fernando has to overcome various obstacles, such as the tempting advances of the enchantress Alcine, from which he is saved at the last moment by a memory of Lea, before he is allowed to leave the island with his beloved. ${ }^{52}$ The librettist thus replaced the rather complex prehistory circling around Prospero's family in Milan with a more straightforward plot around an orphaned child, and he eliminated most of the castaways in Shakespeare's play.

A few decades later, Jules Barbier wrote the libretto for yet another adaptation of The Tempest which was performed at the Paris Opera in $1889 .{ }^{53}$ The initial setting is 'l'espace' ('space'), where angels fly through the clouds and an invisible choir praises God's vigilance. A soul ascends between the clouds; it belongs to Miranda's dead mother who asks the angels to save her child from her uncle's evil intentions. Miranda is left on an island by Stefano rather like Perdita in The Winter's Tale - and he tries to kill her, but an invisible angel protects her and Stefano decides to abandon her 'à la grâce de Dieu' ('to God's mercy'), as he 
'says'. She is then saved by Ariel. Years later, she reigns unchallenged over Caliban and all the spirits on the island - another example for the ballerina's power which is no longer regulated by a dominant man. Miranda causes the shipwreck on a whim and then orders the obedient spirits to rescue the travellers, including Ferdinand with whom she falls in love.'

In both Paris Opera adaptations of The Tempest, there is no father figure for Miranda, and she therefore has to be saved by Christian angels and pagan spirits. Like many nineteenthcentury ballets, both versions were joyfully eclectic: they mix elements and names from several of Shakespeare's texts (Imogen, Oberon) with characters from other works of literature (Alcine from Ariosto's Orlando furioso), the Bible and Greek mythology. Many of the spirits were danced by women, for instance the roles of Ariel, Morpheus and Phantasos.

In the second half of the nineteenth century, male roles were frequently interpreted by female dancers, which reversed casting practices on the Elizabethan stage or in court ballets where most female roles were originally danced by cross-dressed men. In Charles Nuitter's (libretto) and Arthur Saint-Léon's (choreography) ballet Coppélia (Paris Opera, 1870), for instance, a work which was loosely based on E.T.A. Hoffmann's short story Der Sandmann (1816), the main male role was danced by a woman. ${ }^{54}$ This created the unusual situation of a woman rescuing her lover, who was danced by another woman, from the clutches of an evil old man: in the ballet, the magician-toymaker Dr Coppelius tries to infuse life into his manmade creature by killing Franz. The plan is foiled by the young man's courageous fiancée who outwits Coppelius by slipping into the automaton's (pointe) shoes.

It goes almost without saying that many salvage scenes in nineteenth-century ballets followed the traditional pattern of men rescuing women, but the number of heroic ballerinas who deliver their lovers from death or damnation remains striking. One reason for this is 
doubtlessly the spiritual purity and capacity for self-sacrifice attributed to women, which was important in ballets in which salvage was often linked to salvation. Furthermore, the ballerina was so predominant in the nineteenth century that her capacities seemed nearly unlimited and she herself appeared as an almost supernatural being. This impression was enhanced by the development of the pointe technique and the introduction of light, floating costumes which set the female dancers apart from 'ordinary' women.

It is noteworthy that some twentieth-century ballets on similar themes omit the hints at salvation and show both spiritual despair and bodily destruction. If the nineteenth century belonged to the ballerina, the twentieth century saw a new rise of the male dancer, starting with the Ballets Russes and works such as Vaslav Nijinsky's Afternoon of a Faun or Mikhail Fokine's Spectre de la Rose and Petrushka. The role of religion diminished, and supernatural creatures were sent back to their graves like Heine's elementary spirits at the ringing of the morning bells.

\footnotetext{
${ }^{1}$ See the definition of 'salvage' in the Oxford English Dictionary, online edition, last accessed 07.11.2017.

${ }^{2}$ See Lynn Garafola, 'Introduction' in Rethinking the Sylph: New perspectives on the Romantic Ballet, edited by Lynn Garafola (Middletown, CT: Wesleyan University Press, 1997), pp. 1-10 (p. 4).

${ }^{3}$ See For instance Marian Smith, Ballet and opera in the age of Giselle (Princeton: Princeton University Press, 2000), p. 72.

${ }^{4}$ For want of the libretto of the Stuttgart premier, this article is based on the following libretto: Filippo Taglioni, Danina, oder Joko, der brasilianische Affe, idealisches Ballet in 4 Akten, arrangirt vom Ballettmeister Weidmer, no place, no date, which is conserved in the Bavarian State Library in Munich and available online on:
} 
http://daten.digitale-sammlungen.de/ db/0005/bsb00059392/images/, last accessed 07.11.2017. The Taglionis staged Danina in Munich in 1827.

${ }^{5}$ One critic wrote about a performance of Taglioni's ballet in Vienna that the plot was 'vermutlich dem Mazurier'schen Paradestücke nachgebildet' ('probably based on Mazurier's showpiece'), which indicates that the echo of Mazurier's performance in Paris had already reached Austria. See Allgemeine Musikalische Zeitung, 28.41 (October 1826), p. 672.

${ }^{6}$ Cora only tries to shoot a parrot, but misses it several times. See Gabriel de Lurieu and Edmond Rochefort, Jocko, ou le singe du Brésil (Paris: Quoy, 1825), p. 14.

${ }^{7}$ Cited in Ivor Guest, Le Ballet de l'Opéra de Paris: Trois siècles d'histoire et de tradition (Paris: Flammarion, 2001), p. 85. See also Ivor Guest, The Romantic Ballet in Paris (London: Dance Books, 2008), p. 7.

${ }^{8}$ This ballet was based on a 1769 adaptation of Shakespeare's play by Jean-François Ducis which was very popular on the French stage in the late eighteenth and early nineteenth century. See Louis Henry, Hamlet, pantomime tragique en 3 actes, mêlée de danses, par Louis Henry, musique du comte de Gallenberg, Paris, Porte St-Martin, 28 février 1816 (Paris: Barba, 1816).

${ }^{9}$ According to Manuela Jahrmärker, Scribe hesitated to choose this ending, which was atypical for the genre: a first draft of his libretto ended happily. See Manuela Jahrmärker, Comprendre par les yeux: Zu Werkkonzeption und Werkrezeption in der Epoche der Grand Opéra (Laaber: Laaber-Verlag, 2006), p. 217.

${ }^{10}$ See Marian Smith, Ballet and opera, pp. 53-54.

${ }^{11}$ Eugène Scribe, Manon Lescaut, ballet-pantomime en trois actes, chorégraphie de Jean-Pierre Aumer, argument d'Eugène Scribe, musique de Jacques-Fromental Halévy, représenté pour la première fois, à Paris, sur le théâtre de l'Académie royale de musique, le 30 avril 1830 (Paris: Bezou, 1830), Act 3, Scene 10, p. 41. Unless otherwise stated, all translations are my own.

${ }^{12}$ See the 2004 DVD of Kenneth MacMillan's Manon with Jennifer Penney and Anthony Dowell (Royal Ballet, 1982).

${ }^{13}$ See Eugène Scribe et Germain Delavigne, Robert-le-diable, opéra en cinq actes, paroles de MM. Scribe et Germain Delavigne, musique de J. Meyerbeer, représenté pour la première fois, à Paris, sur le théâtre de l'Académie royale de musique, le 21 novembre 1831 (Paris: Bezou, 1831). 
${ }^{14}$ See Adolphe Nourrit, La Sylphide, ballet en 2 actes, par M. Taglioni [choreography], Paris, Académie royale de musique, 12 mars 1832 (Paris: J.-N. Barba, 1832).

${ }^{15}$ Cited in Edwin Binney, Les ballets de Théophile Gautier (Paris: Nizet, 1965), p. 22.

${ }^{16}$ Parmenia Migel, Great ballet prints of the Romantic era (New York: Dover Publications, 1981), VII.

${ }^{17}$ Théophile Gautier, 'Giselle, ou les Wilis' in Théâtre: Mystère, comédies et ballets (Paris: Charpentier, 1872), pp. 331-378 (p. 359).

${ }^{18}$ See for instance Peter Wright on www.roh.org.uk/news/getting-it-right-peter-wright-on-his-production-ofgiselle, accessed 07.11.2017: 'I am insistent that Giselle actually kills herself as in the original production, which is why she is buried in unhallowed ground, unprotected from the evil Wilis.' On the question whether Giselle commits suicide See Marian Smith, 'What killed Giselle?', Dance Chronicle, 13.1 (1990), 68-81, and my article 'Dances of death from Paris to Saint Petersburg: Suicides in ballet', European Drama and Performance Studies, 7 (2016), 171-184 (pp. 173-175).

${ }^{19}$ See Joseph Mazilier, Aelia et Mysis ou l'Atellane, ballet-pantomime en deux actes, chorégraphie et argument de Joseph Mazilier, musique d'Henri Potier, Paris, Académie impériale de musique, 21.09.1853 (Paris: Veuve Jonas/ Michel Lévy Frères, 1853).

${ }^{20}$ See Ivor Guest, The ballet of the Second Empire, London: Pitman, 1974, p. 218.

${ }^{21}$ See Cyril W. Beaumont, Complete book of ballets: A guide to the principal ballets of the nineteenth and twentieth centuries (London: Putnam, 1951), p. 175.

${ }^{22}$ Ivor Guest states that Goethe's Faust was Perrot's 'principal source', whereas the scene in which the Seven Deadly Sins tempt Marguerite evokes Marlowe's Doctor Faustus. See Ivor Guest, Jules Perrot: Master of the Romantic Ballet (London: Dance Books, 1984), p. 209. Manuela Jahrmärker states that the sources of the ballet were an 1828 French adaptation of Goethe's play by Béraud, Merle and Nodier, which ends with Faust's damnation, and an earlier ballet choreographed by Deshayes (London, 1833). See Manuela Jahrmärker, Themen, Motive und Bilder des Romantischen: Zum italienischen Musiktheater des 19. Jahrhunderts (Berlin: LIT Verlag, 2006), 38 .

${ }^{23}$ Heine's ballet, which he wrote at Benjamin Lumley's request for Her Majesty's Theatre, was never staged, probably due to its potential for scandal. See Iris Julia Bührle, Literatur und Tanz: Die choreographische 
Adaptation literarischer Werke in Deutschland und Frankreich vom 18. Jahrhundert bis heute (Würzburg:

Koenigshausen \& Neumann, 2014), pp. 139-158.

${ }^{24}$ See www.spiegel.de/spiegel/print/d-44435466.html, last accessed 17.11.2017.

${ }^{25}$ See Werner Egk's libretto for Abraxas in Thomas Poeschel, Abraxas Höllen-Spectaculum: Ein zeitgeschichtliches Libretto des deutschen Nationalmythos von Heinrich Heine bis Werner Egk (Berlin: Hentrich \& Hentrich, 2002), pp. 184-190.

${ }^{26}$ See the libretti in Roland John Wiley, Tchaikovsky's ballets (Oxford: Clarendon Press, 1985), pp. 326-327 (1877) and p. $341(1895)$.

${ }^{27}$ See the entry 'La Bayadère' in the Oxford Dictionary of Dance, ed. by Debra Craine and Judith Mackrell (Oxford: OUP, 2010).

${ }^{28}$ However, this ending is changed in many modern productions of Giselle which focus instead on Albert's poetic despair over the loss of Giselle.

${ }^{29}$ See Roland Petit in the programme of his ballet Clavigo (Paris: Opéra National de Paris, 1999), p. 62.

${ }^{30}$ See the 2004 DVD of Roland Petit's Clavigo with Clairemarie Osta and Nicolas Le Riche (Paris Opera Ballet, 1999).

${ }^{31}$ This constellation recalls Jerome Robbins's 1951 ballet The Cage, which is set among a community of insectlike female creatures who kill and devour their mates. In this short ballet, the young novice murders her first mate without regret, but apparently develops feelings for a second partner, whom she initially tries to protect from her fellow creatures and their leader. Unlike Giselle, however, she eventually participates in the killing. ${ }^{32}$ Paul Foucher, Paquita, ballet-pantomime en 2 actes, par MM. Paul Foucher [libretto] et Mazilier [choreography], musique de M. Deldevez, Paris, Académie royale de musique, 1er avril 1846 (Paris: Veuve Jonas, 1846).

${ }^{33}$ See Arthur Saint-Léon, Stella, ou les contrebandiers, ballet-pantomime en 2 actes, chorégraphie et livret d'Arthur Saint-Léon, musique de Cesare Pugni, Paris, 22.02.1850, Opéra (Paris, Veuve Jonas, 1850).

${ }^{34}$ See Guest, Jules Perrot, pp. 112-126.

${ }^{35}$ See Guest, Second Empire, pp. 75-76.

${ }^{36}$ See ibid., pp. 98-99. 
${ }^{37}$ Susan Au, 'The bandit ballerina: Some sources of Jules Perrot's Catarina', Dance Research Journal, 10.2 (1978), 2-5 (p. 3).

${ }^{38}$ See Lynn Garafola, 'The travesty dancer in nineteenth-century ballet', Dance Research Journal, 17.2 (1985), 35-40 (p. 38).

${ }^{39}$ See the libretto of Catarina, ou la fille du bandit, a ballet in five tableaux by Mr. Perrot (libretto and choreography), the music by Signor Pugni, produced at Her Majesty's Theatre, March the $3^{\text {rd }}, 1846$ (London: S. G. Fairbrother, 1846). Susan Au has identified several possible sources for the scenario of the ballet, including a description of an engraving by Salvator Rosa in Lady Morgan's work The life and times of Salvator Rosa (published in 1824). Au also highlights the similarity of the ballet plot to that of the comic opera Les Diamants de la couronne that was first performed at the Opéra-Comique in Paris in 1841, and which featured a bandit called Catarina. Its libretto was written by Eugène Scribe and Jules-Henri Vernoy de Saint-Georges, who also authored several ballet libretti. The opera did not end with Catarina's death and spectacular rescue of her lover, but concluded happily with the revelation that she is actually the Queen of Portugal. On Catarina and its possible sources, See Susan Au, 'Bandit Ballerina'. See also Guest, Jules Perrot, pp. 157-159.

${ }^{40}$ See Beaumont, Complete book, p. 141.

${ }^{41}$ Jules Janin in Journal des débats, 6 December 1833, cited in translation in Guest, Romantic Ballet in Paris, p. 231.

${ }^{42}$ The harem scenes also reflected the dismal reality of the dealings between mostly underpaid female dancers and rich male patrons which happened backstage at the Paris Opera. This subject shall not be discussed at length here, even though the male audience's passionate interest in the danseuses contributed in its own way to the rising importance of women in ballet. The sheer implausibility of certain scenes of female dominance - such as the appearance of women in armour at the end of La Révolte au sérail-makes them seem like harmless male fantasies in an age in which the workplace of the seemingly unattainable ballerina was also a setting of social misery and prostitution.

${ }^{43}$ Joellen A. Meglin, 'Feminism or fetishism? La Révolte des femmes and Women's Liberation in France in the 1830s' in Rethinking the Sylph, pp. 69-90 (p. 69).

${ }^{44}$ On similar developments and cross-dressing in the spoken theatre see Wendy C. Nielsen, Women Warriors in Romantic Drama (Newark: University of Delaware Press, 2012). However, Nielsen states that the woman 
warrior in German, French and British art and drama usually fights for her ideals alone 'as a suffering redeemer, a woman who sacrifices herself for others' sins' (p. 137), which contrasts with the scenes of female rebellion in some Romantic ballets.

${ }^{45}$ Jules Janin in Journal des débats, 13 April 1835, cited in translation in Guest, Romantic Ballet in Paris, pp. 247-248.

${ }^{46}$ See Guest, Jules Perrot, pp. 263-266.

${ }^{47}$ This plot evokes the so-called 'rescue opera' which appeared in Germany and France in the late eighteenth and early nineteenth century. Roland John Wiley writes: 'The rescue opera, familiar from the example of Beethoven's Fidelio, is based on clearly prescribed characters and situations: a righteous leading character has been imprisoned by an unprincipled villain, but is freed by loyal followers in circumstances of great dramatic tension.' He adds that the rescue is usually carried out by a 'faithful spouse or lover'. See Roland John Wiley, $A$ century of Russian ballet (New York: Oxford University Press, 1990), p. 50. Several of Charles Didelot's ballets were inspired by this genre, for instance his Raoul de Créqui (Saint Petersburg, 1819) and Le Prisonnier du Caucase (Saint Petersburg, 1823). In both ballets, women save the lives of men or boys; in Raoul, a woman even stabs a soldier to death 'like an enraged lioness' in order to rescue her son. See. the libretto in Wiley, Russian Ballet, p. 60.

${ }^{48}$ See Guest, Jules Perrot, pp. 262 and 267. In the original libretto, the young man who is placed on the throne by the women is not the rightful duke, a fact that was apparently resented by the censor. Therefore, it is unlikely that the first libretto featured the intervention of a statue of the legitimate duke and of supernatural powers which restore the 'natural' order.

${ }^{49}$ See Cyril W. Beaumont, Supplement to Complete book of ballets (London: C. W. Beaumont, 1942), pp. 23-26.

${ }^{50}$ See Ivor Guest, The Romantic Ballet in England (London: Phoenix House, 1954), p. 58.

${ }^{51}$ See Hélène Laplace-Claverie, Écrire pour la danse: Les livrets de ballet de Théophile Gautier à Jean Cocteau (1870 - 1914) (Paris: Champion, 2001), p. 160.

${ }^{52}$ See Adolphe Nourrit, La Tempête, ou l'île des génies, ballet-féerie en deux actes, précédé d'une introduction, livret d'Adolphe Nourrit, chorégraphie de Jean Coralli, musique de M. Schneitzhoeffer, représenté pour la première fois, à Paris, sur le théâtre de l'Académie royale de musique, le 10 septembre 1834 (Paris: Barba, 1834). 
${ }^{53}$ Jules Barbier, La Tempête, ballet en trois actes, six tableaux, livret de Jules Barbier, chorégraphie de Joseph Hansen, musique d'Ambroise Thomas, Paris, Opéra, 26 juin 1889 (Paris: Calmann Lévy, 1889).

${ }^{54}$ See Charles Nuitter, Coppélia, ou la Fille aux yeux d'émail, ballet en 2 actes et 3 tableaux, de Charles Nuitter [libretto] et A. Saint-Léon [choreography], musique de Léo Delibes, Paris, Opéra, 25 mai 1870 (Paris: E. Dentu, 1870). 